International Journal of Business and Management Future; Vol. 4, No. I; 2020

ISSN 2575-79II E-ISSN 2575-792X

Published by Centre for Research on Islamic Banking \& Finance and Business, USA

\title{
An Assessment of the Determinants of Environmental Costs of Listed Deposit Money Banks in Nigeria
}

\author{
Wasiu Adebayo Lamidi \\ $\mathrm{PhD}$ Student \\ The Postgraduate College \\ Osun State University, Osogbo, Nigeria \\ E-mail: lamwas4u@yahoo.com \\ Adesola Olufunmilola Oluwatuyi \\ $\mathrm{PhD}$ Student \\ The Postgraduate College \\ Osun State University, Osogbo, Nigeria \\ E-mail: christmat27@gmail.com \\ Tariro Masunda \\ Assistant Accountant \\ Postal and Telecommunication Regulatory Authority of Zimbabwe \\ E-mail: tarimasunda@gmail.com \\ Adebayo Olagunju \\ Senior Lecturer \\ Department of Accounting \\ Osun State University, Osogbo, Nigeria \\ E-mail: heavenisreal36@gmail.com
}

\begin{abstract}
This paper assesses the determinants of environmental costs of Nigerian banking institutions. Looking at the influence of profitability, company size and leverages on environmental cost such as donation, gift and developments, the population of the study are deposit money banks in Nigeria. Using purposive sampling technique, the study selected all fifteen (I5) banks listed on the Nigerian Stock Exchange websites as at June 3I, 2019 in which their annual reports are available to be extracted. The study utilized archival data i.e the annual report of listed banks from $2014-2017$ to extract the needed information. Using STATA I4 software, the study conducts diagnostic tests such as heteroskedasticity, multicollinearity and Pearson correlation for data examination. Hence, multiple regression analysis was conducted to investigate the influence of profitability, company size and leverages on environmental costs. The analysis of the study showed that profitability, company size and leverages have positive and significant association with the environmental cost reported by these banks. Therefore, the study recommended that to adapt to the changing system of doing business, accountants ought to be equipped with skills and knowledge about environmental accounting and reporting, and in order to enhance competitiveness, banks must design and apply environmentally friendly strategies.
\end{abstract}

Keywords: Banks, Environmental Cost, Profitability, Company Size, Leverages.

\section{Introduction}

The consciousness of the man's surroundings and his capability to be destructive of the environment began in the fifties of the I9th century. This anxiety had continuously been articulated in successive international conferences and agreements dating back to the sixties. The starting point that composed an organized through proves a large scale the celebrated public action of the club of Rome entitled "Limit to Growth that initiated a worldwide debate of economic growth at the expense of natural environment (Susi, 2005).

In modern times, the development of the economy has adversely affected the environment and the communities the world over are greatly concerned about this issue. Increasingly environment is attracting increased urgent economic, social and 
political difficulties. Accountants being the stewards and promoters of economic growth are not able to turn a blind eye to how environmental matters impact on business management, accounting, audit and system of disclosure. Environment preservation and the possible participation of accountant is now being commonly discussed among accountants globally. In this day and age, there is an expectation for accountants to proactively participate in protection of the environment. This is owing to liberalisation which removed barriers to trade, thus making it reasonable for expenses of environmental degradation resulting from industrial activities to be incorporated into company account to the possible magnitude. Therefore, environmental accounting and reporting are significant today.

The association concerning business and the environment has turned out to be more and more vital as a result of an upsurge in environmental consciousness. Owing to this, social and environmental performance has been an area of interest in accounting literature for many years. Research on environmental consciousness and its impact on company's performance are not concluded (Ahmed et al., 2003). Study by Bassey et al., (2013) states that environmentally related costs have a positive effect on the profit-making ability of a company and the performance of an organisation. The study also found that big companies report considerably as well as disclose information which is related to the environment, and that environmentally friendly organizations which are conscious of their environment enjoy increased degrees of corporate cooperativeness. Furthermore, the absence of environmental reporting and disclosure standards is found to considerably impact on the manner in which companies report and disclose consistency of environmentally connected information in financial statements and annual reports (Bassey et al., 20I3).

In addition, Selcuk \& Kiymaz (2017) in their study which cantered on the association concerning how companies perform corporate social responsibility of Istanbul listed firms using content analysis of yearly reports/websites of firms in Turkey for any socially responsible activities found that an adverse link exists between corporate social responsibility and financial performance. This means that companies which engage in increased information disclosure related to corporate social responsibility activities in their annual reports achieve lesser return on assets. Adjusting for company debt and size it is found that companies with increased amount of leverage record lower profits, bigger companies are more profitable and that no noteworthy relationship exists about research and development costs and performance of the firm (Selcuk \& Kiymaz, 2017).

Prior studies in the field of accounting have studied the association between environmental performance and environmental disclosure. Bowman \& Haire (1975); Abbot \& Monsen (1979) showed how environmental performance and environmental disclosure are positively related. In the meantime, Fry \& Hock (I976)'s association of the two variables was negative. As a result, the purpose of the current research is to investigate the relationship between environmental costs (e.g. social costs which includes donations, R\&D and gift to charitable organization) and financial performance of listed banking institutions in Nigeria.

\section{I.I Objective of the Research}

In a bid to accomplish the purpose of this research, the study aims to achieve the following objectives:

- To examine the relationship between profitability and environmental costs of listed deposits money Banks in Nigeria.

- To examine how company size influences the environmental costs of listed deposits money Banks in Nigeria.

- To examine the relationship between leverages and environmental costs of listed deposits money Banks in Nigeria.

\section{Literature Review \\ 2.I Conceptual Review}

Many companies' executives support that an economy's key aim is that of sustainably developing. Sustainability necessitates businesses to make every effort for eco-efficiency; however, they can only quantify that by generating correct information on environmental expenditures as well as revenues and environmental performance. Expenses relating to the environment are one of the several various kinds of expenses that companies bear in their aim to ensure the provision of products to consumers. Environmental performance is an example of the numerous significant determinants of corporate accomplishment.

Corporations have reacted favourably to the requirement for an improved method of conducting their commercial activities which gives regard to society's wellbeing as the people now analyses their business processes more than it used to in the past. McWilliams \& Siegel (2000) stated that a sustainability report offers data based on economic, environmental, social, and governance performance. A sustainability report is thus a vital instrument for businesses to tête-à-tête about the favourable and unfavourable impact of sustainability, thus aiding in the fulfilment of corporate goals, evaluating their outcome as well as change management.

Corporate social responsibility is viewed as a beneficial structure by which innovative methods of teamwork amid enterprises, states and the public may result in the developing of novel methods of governance centred on business ventures. The reports relating to corporate social responsibility reveal the relationship between corporate social responsibility and social partnerships cherished not only as a social problem-solving device but also as an instrument to develop effectiveness and sustain the society at an indigenous level. In recent times, there have been differing beliefs regarding the reassessment of the indigenous aspect concerning sustainability and social responsibility, as well as relating to international competitiveness. 


\subsection{Theoretical Review}

This study underpins legitimacy theory; this theory states that the business and the neighbouring areas ought to foster social associations, as they are all involved in a "socially stated contract". Social contract theory denotes how corporate existence in a region for political support and assured by government rules and the parliament is also a representation of the community. Therefore, there are unforeseen social contract connecting the business and the public in which the public allocates expenditures and profits for corporate progression (Lako, 20II). Social contract was made as the media to set the order (order of) social life of the community. The legitimacy philosophy is a structure of business administration, dedicated to the public (society), distinct organizations and public entities. Resultantly owing to it being a structure that highlights arrangements to the public, the corporation's actions ought to be in agreement with society's anticipations (Hilmi, 2016).

Nevertheless, the worldwide financial crisis and the money market unpredictability of forced companies to re-examine their value systems as well as highlight the significance legitimacy. The relationship between tangible financial resources with intangible legitimacy resources is vital for influencing a new administrative vision. Several researchers have critiqued the elevation of the theory of legitimacy in this regard (Mobus, 2005; Owen, 2008). Legitimacy theory was from time to time viewed merely as a "reasonable justification of management inspirations" devoid of some tangible determination to define the manner in which disclosing information might encourage transparency and accountability in the direction of groups of stakeholders who do not provide capital. According to Owen (2008) the legitimacy theory is a hypothetical concept which researchers use to make feasible extrapolations. As a result, corporations ought to reveal social and environmental information in a bid to reflect their fairness as an entity. The association linking legitimacy and resources appealed to and still captures the responsiveness of scholars who embark on social and accounting studies (Mobus, 2005; Tilling \& Tilt, 2010). According to their view, information disclosure ought to be complemented with actual activities recognized in agreement with social and environmental standards and principles.

Also, when a firm considers its public appearance in its external environment, this in turn improves or preserves cognitive legitimacy. The business intends to attain acknowledgment from its key participants (e.g., employees, customer, media, and financial institutions) for temporary ventures with an instant and dominant prominence. Such immediate ventures aimed at preparing the way for viable capacity expansion (Schiopoiu-Burlea \& Popa, 2013). Legitimacy works at numerous stages, nonetheless for a business, the consideration of industry standards and acting in their obedience is vital. For instance, the environmental incidents brought about by the corporations which include Exxon Valdez, Shell, BHP Limited, and Alcoa have resulted in a negative effect on the whole reputation of the industry, hence firms in this industry have been alleged as a pollutant and negligent industry. The bad media reporting of these occurrences produced an upsurge of anxieties of the public about social and environmental accountabilities and exerted force on the establishments to take into account a thorough disclosure of the environmental information in their annual report. As a result, legitimacy is a significant resource which cannot be seen or touched and like whichever resource, it ought to be administered prudently, particularly if the company's reputation has been tainted or negatively impacted by key events (Tilling \& Tilt, 20I0). The socio-economic as well as environmental complications call for companies to responsibly handle some risks which may have negative impact on their legitimacy. The additional business scandals (i.e., BP Oil Spill, Bhopal Disaster, Parmalat, Andersen, HealthSouth Corporation, KPMG, The AIG, and Enron) resulted from the firms not considering the legitimacy theory in their day to day operations.

Additionally, external and internal evidences are collected to enable the improvement of the legitimacy life cycle, considering previous familiarities and prospective approaches. The inter-relation between the legitimacy types and the interior and exterior environment of the company showed the significance of ethical legitimacy in supporting pragmatic legitimacy. The sturdy connection existing between the business and the society's norms which it triggers enables the firmness of the lawfulness to be founded on practicable inputs and outputs of the business and time and again demonstrates a limiting aspect for the other company undertakings, but in agreement with the norms and beliefs of the society (Dowling \& Pfeffer, I975).

Therefore, the value of the legitimacy is influenced by the management as these have the duty of assuring the relations of both the external and internal environment and to avoid future loss of the firm's reputation as well as indirectly of its pragmatic legitimacy. Consequently, the management of the company and legitimacy are interconnected and favourably impact each other to enable the fulfilment of goals of social, environmental and economic nature.

\subsection{Empirical Review}

Susi (2005) in their study which examines the association between environmental and financial performance documents adverse relationship. The writers envisage that if an organisation concentrates more on protecting and improving the environment, this will result in an increase in environmental costs but this will in turn lessen profits of the firm. As a result, performance of the company financially will be negatively impacted. QinYing \& W-Chun (2005) in their study on the association between environmental performance and financial performance using the pollution emission index and return on equity. The population of the study were transport industry listed on China Shanghai Stock Exchange. The study showed a negative correlation between corporate environmental protection and financial profit performance. Henri \& Journeault (20I0) established that the environmental information of a company in relative to financial index data will affected depending on the period and particular 
context modification; hence the two are not significantly correlated. Additionally, Herawaty (2018) concluded that environmental performance and profitability positively impact on earnings informativeness, whereas leverage is negatively related to earnings informativeness. Furthermore, the researchers indicated how this type of information might help stakeholders in examining the attributes impacting earnings informativeness to be utilised when making a consideration whether or not to invest in an organisation, engage in share disposal as well as preserve their shares in anticipation of a profitable investment return for investors. Another research carried out by Rakhiemah \& Agustia (2009) which used Indonesian Stock Exchange Listed Companies, established that environmental performance significantly influences disclosure of Corporate Social Responsibility by entities.

By using the agency theory (Jensen \& Meckling, 1976) asserted how political transmissions of wealth, from debt holders to equity holders may occur in companies with high levels of debt. Agency theory envisages that restrictive covenant ought to be incorporated into debt agreements to ensure that the economic interests of the company are safeguarded. For the purpose of monitoring, managers can volunteer to reveal information in the firm's financial report. Accordingly, agency theory envisages how the propensity to voluntarily disclosure information by a company increases as the company expands. Leftwich et al., (I98I) proposes how the amount of external capital has a tendency to be greater for bigger companies as the possible benefits of voluntary disclosure escalates with stockholder debt holder-manager encounters. Moreover, highly leveraged companies' businesses with high leverage may disclose more information to fulfil the needs of long-standing creditors as well as to eradicate mistrust of bondholders as regards allocation of wealth (Myers, 1979).

However, Lang \& Lundhlom (1993) suggest the existence of a particular uncertainty in theoretical and empirical research with regards to profitability and relative to disclosure, hence a non-monotonic connection concerning disclosure and profitability. This is owing to the fact that companies which make lesser profits might reveal increased amount of information to give details the causes for the adverse performance and provide the market with reassurance regarding progress in the future. Businesses as well reveal information that is unfavourable at a timely chance in a bid to reduce legal liability risk, major reduction of share capital and reputation loss (Skinner, 1994).

This study shall examine the association of environmental costs which includes donation, gift and development of listed deposit money banks and its performance.

\section{Methodology}

This study employed quantitative method in conducting this research. Quantitative methods pave way for the collection of data using archival information. It generates numerical data that can thereafter be converted into numbers. In quantitative study, large population can be reached and can make the end result of the study to be generalized. For quantitative research there is need for both primary and secondary data to be collected. This type is suitable for examining the influence of banks financial performance on environmental costs (Zikmund et al., 20I0; Sekaran, 2003).

The research technique adopted in this study makes use of an investigation of a sample of listed firms' annual reports to appraise or examine the influence of banks performances on environmental costs. Using purposive sampling technique, the study selected all fifteen (I5) banking institutes listed on the Nigerian Stock Exchange websites as at March 3I, 2019. Annual reports are used to extract historical data to be utilized for this study. This provides a ground for the collection of related data to variables from the archival information of companies. The website of Nigeria Stock Exchange and possibly corresponding company websites were used to extract the annual reports of the listed companies. This study follows prior research which utilized annual report as their source of data collection (Abbott et al., 2003; Ayoib et al., 2006; Bhasin, 2016).

In the current study data extracted from annual report were scrutinised using STATA I4. This analysis comprises of descriptive statistics and regression analysis.

\section{Findings and Discussion}

Before proceeding to regression analysis, there is need to carry out diagnostics tests to examine the efficiency and accuracy of our data. In order to examine these assumptions, heteroskedasticity test, Ramsey test and normality test are conducted.

\section{I Heteroskedasticity and Ramsey test of Model Specification}

Varying tests can be utilized in order to identify the heteroscedasticity issue, such as the white's General Heteroskedasticity Test, Spearman's Rank Correlation Test, Park Test, Goldfeld-Quandt Test, Glejser Test and Breusch-Pagan-Godfrey Test. The current study only utilized Breusch-Pagan-Godfery/Cook-Weisberg Test to check for the existence of homoscedasticity among the error terms (Gujarati \& Porter, 2012).

As suggested by Gujarati \& Porter (2009) the problem of heteroskedasticity can be ratified with the utilization of White Heteroscedasticity Consistent Variance with the Standard error technique which can as well be corrected in the robust regression analysis with the aid of Stata software. 
Table I.Test for Model Specification and Heteroscedasticity

\begin{tabular}{llll}
\hline & Chi2 & F & P - Value \\
\hline Breusch-Pagan Test & 3I.22 & - & 0.0015 \\
\hline Ramsey Test & - & 6.65 & 0.1009 \\
\hline Ho (null) & reject & Reject \\
\hline \multicolumn{4}{c}{ Note: Ho (null): Constant variance (homoscedasticity) }
\end{tabular}

Statistically the Ramsey Regression Equation Specification Error Test (RESET) test is generally referred to as the specification test within the linear regression model. It helps to examine the instance of non-linear blends of fitted values assisting to describe the response variable. The reason for this test is the fact that if non-linear blends of the explanatory variables have any impact in explaining the response variable, means the model is misrepresented (Ramsey, I974; Semykina \& Wooldridge, 2013). Based on Table I, the significance of Breusch-Pagan Test with $p$-values less than 0.05 indicates that there is heteroscedasticity problem in our model, resulting to the rejection of the hypothesis that state that no heteroscedasticity. On the other hand, Ramsey test non-significant means that the model is not misrepresented. Due to this problem, robust regression analysis was conducted to correct the problem of heteroscedasticity as suggested by Gujarati \& Porter (2009).

\subsection{Pearson Correlation}

In order to identify the relationship that exists between dependent and other variables. Pearson correlation matrix is used to show the direction, significant and strength of the association between variable before examining the coefficient of regression. Generally, in behavioural sciences correlation coefficient of .IO, .30 and .50 is respectively referred to as low, medium and high coefficient. Pallant (20II) states that the correlation analysis is important in depicting the direction and strength of the linear relationship amongst two variables. More precisely, the Pearson correlation analysis was undertaken to clarify and assess the strengths of the relationship amongst the study variables as presented in Table 2 . The correlation coefficient $(r)$ values presented in the Table 2 displays the strength of the relationship among variables.

Table 2. Summary of Pearson correlation $(N=60)$

\begin{tabular}{lccll}
\hline & DCG & SIZE & PAT & LEVERAGE \\
\hline DCG & I & $.505^{*}$ &.$I I 2^{*}$ & $0.257^{*}$ \\
\hline SIZE & I & $.68 I^{*}$ & -0.018 \\
\hline PAT & & I & -0.104 \\
\hline LEVERAGE & & & I \\
\hline & & &
\end{tabular}

\subsection{Multicollinearity Test}

Multicollinearity is utilized to check if there exists any relationship among the independent variables. This can be clarified by the level of which any variable effect can be anticipated with the other variable (Hair et al., 2010).

Hence, a typical approach utilized for appraising whether there is multicollinearity is called the Variance Inflation Factor (VIF). Independent variable is thought to be profoundly related if the estimation of Variance Inflation Factor (VIF) is above IO, bringing about an issue of multicollinearity. There is no multicollinearity problem if the value of VIF is less than IO (Pallant, 20II; Hair et al., 2012; Sekaran \& Bougie, 2013). Table 3 shows the Variance inflation factor for the variables is not greater than IO. This indicates that the assumption of multicollinearity has not been violated.

Table 3. Multicollinearity Test Summary

\begin{tabular}{lll}
\hline Variable & VIF & I/VIF \\
\hline PAT & I.90 & 0.526649 \\
\hline SIZE & I.87 & 0.535626 \\
\hline LEVERAGE & 1.03 & 0.974315 \\
\hline Mean VIF & I.60 & \\
\hline
\end{tabular}

Note: $D C G=$ Donation to Charitable and Gift, PAT = Profit after tax, SIZE $=\log$ of total asset, Leverage $=$ debt to equity ratio. 


\subsection{Regression Analysis}

In order to investigate the hypothesis model there is need for the $R^{2}$ ( $R$ Square) coefficient which verified the robustness of the equation of regression. This can as well be referred to as the coefficient of determination. The $\mathrm{R}^{2}$ in this study assess the differences of the environmental cost (e.g donation and charitable gift, research and development) which is measured by donation and charitable gift, research and development and its influence by the independent variable such as profit after tax, company size which is measured by log of total asset and as well leverage. Besides, when the $\mathrm{R}^{2}$ is proportionate to $\mathrm{I}$ that infers that there is a magnificent direct association among the dependent and independent variable in the study. Also, when $\mathrm{R}^{2}$ is close or equivalent to 0 , this suggests no direct association existing among the dependent and the independent variable. Subsequently, the unit under $\mathrm{R}^{2}$ shows the level of distinction in the dependent variable (environmental cost which is measured donation, gift and developments) is being depicted in the model which includes Profit after tax, company size and leverages.

Table 4 shows that adjusted $\mathrm{R}^{2}$ rate is in model is .3878 . This indicates that the model contributes $39 \%$ of changes in dependent variable which is measure by donation and gift to charity. In behavioural science this result is considered an acceptable result of an empirical study. This result is achieved with the aid of STATA I4 software. Tabachnick \& Fidell (2007), states that in any cases where the population sample is small result of the study especially $\mathrm{R}^{2}$ value can be rather optimistic of the value of the population. The value of the adjusted $\mathrm{R}^{2}$ shows that the donation and gift to charity which is the dependent variable is explained by $39 \%$ changes in the independent variables of this study. The implication is that the deviation in donation and gift to charity is explained statistically by the equation of regression in this study. Model of this study is significant at $p$-value less than 0.0I, this indicate the significance of the model to the study.

In analysing the result and to test the hypothesis, coefficient or the weight of regression is needed. The negative or positive indicate the direction of the relationship between the dependent variable and the independent variables. Taking into consideration only the weight of the coefficient, this shows that any variables having the highest standardized beta or weight is considered the most significant and the most predictor of the dependent variable. Also, in order to identify the significance of the variable probability value can as well be examined. Independent variables are said to be significant predictor of the dependent variable at p-value less than $0.0 \mathrm{I}, 0.05$ and 0.10 respectively.

Table 4 shows that the three variables are significant to environmental costs as measured by donation, gift to charity and development. The significant variable as indicated by their beta or weight of the regression and as well as the probability value are profit after tax (PAT) with beta of 0.194 and $\mathrm{p}$ - value of 0.018, company size (SIZE) with 0.705 and $\mathrm{p}-$ value of 0.000 , and lastly the leverage (LEVERAGE) with beta of I.704 and p - value of 0.024 .

In order to investigate the hypothesis model there is need for the $R^{2}$ ( $R$ Square) coefficient which verified the robustness of the equation of regression. This can as well be referred to as the coefficient of determination. The $\mathrm{R}^{2}$ in this study assess the differences of the environmental cost (e.g donation and charitable gift, research and development) which is measured by donation and charitable gift, research and development and its influence by the independent variable such as profit after tax, company size which is measured by log of total asset and as well leverage. Besides, when the $\mathrm{R}^{2}$ is proportionate to $\mathrm{I}$ that infers that there is a magnificent direct association among the dependent and independent variable in the study. Also, when $\mathrm{R}^{2}$ is close or equivalent to 0 , this suggests no direct association existing among the dependent and the independent variable. Subsequently, the unit under $\mathrm{R}^{2}$ shows the level of distinction in the dependent variable (environmental cost which is measured donation, gift and developments) is being depicted in the model which includes Profit after tax, company size and leverages.

Table 4 shows that adjusted $\mathrm{R}^{2}$ rate in model is .3878 . This indicates that the model contributes $39 \%$ of changes in dependent variable which is measure by donation and gift to charity. In behavioural science this result is considered an acceptable result of an empirical study. This result is achieved with the aid of STATA I4 software. Tabachnick \& Fidell (2007) states that in any cases where the population sample is small result of the study especially $R^{2}$ value can be rather optimistic of the value of the population. The value of the adjusted $\mathrm{R}^{2}$ shows that the donation and gift to charity which is the dependent variable is explained by $39 \%$ changes in the independent variables of this study. The implication is that the deviation in donation and gift to charity is explained statistically by the equation of regression in this study. Model of this study is significant at $p$-value less than 0.0I, this indicate the significance of the model to the study.

In analysing the result and to test the hypothesis, coefficient or the weight of regression is needed. The negative or positive indicate the direction of the relationship between the dependent variable and the independent variables. Taking into consideration only the weight of the coefficient, this shows that any variables having the highest standardized beta or weight is considered the most significant and the most predictor of the dependent variable. Also, in order to identify the significance of the variable probability value can as well be examined. Independent variables are said to be significant predictor of the dependent variable at $\mathrm{p}$-value less than $0.0 \mathrm{I}, 0.05$ and 0.10 respectively.

Table 4 shows that the three variables are significant to environmental costs as measured by donation, gift to charity and development. The significant variable as indicated by their beta or weight of the regression and as well as the probability value are profit after tax (PAT) with beta of 0.1943826 and $\mathrm{p}-$ value of 0.018 , company size (SIZE) with 0.7047093 and $\mathrm{p}-$ value of 0.000 , and lastly the leverage (LEVERAGE) with beta of 1.70376 and $p$ - value of 0.024 . 
Table 4. Result of robust regression analysis (Dependent variable $=D C G$ )

\begin{tabular}{|c|c|c|c|c|}
\hline Variables & Expected Sign & Coefficient & $\mathrm{t}$-value & $\mathrm{P}$ - value \\
\hline PAT & + & 1.608795 & $5.08^{\text {thx }}$ & 0.018 \\
\hline SIZE & + & 0.704709 & $2.45^{2}$ & 0.000 \\
\hline LEVERAGE & + & 1.70376 & $2.33^{x}$ & 0.024 \\
\hline Number of Obs & & & 60 & \\
\hline $\mathrm{F}(\mathrm{II}, 88)$ & & & 10.92 & \\
\hline $\mathrm{R}^{2}$ & & & .42684 & \\
\hline Adjusted $\mathrm{R}^{2}$ & & & .3878 & \\
\hline Prob $>F$ & & & 0.0000 & \\
\hline
\end{tabular}

$$
\text { Coefficient is significant at } 0.01
$$

Note: $D C G=$ Donation to Charitable and Gift, PAT $=$ Profit after tax, SIZE $=$ log of total asset, Leverage $=$ debt to equity

\subsection{Hypotheses Testing}

ratio.

\section{Hypothesis I: Environmental costs have positive association with firm's profitability}

As depicted in table 4, there is clear indication with the weight or coefficient of regression that profitability (proxy with profit after) has positive and significant association with environmental costs (measured with donation, gift to charity and development). The implication of these findings is that, the more the company is able to make as profit, the more they would spend on environment costs and vice versa. This study is in tandem with study of Herawaty (2018) which states that environmental performance and profitability has a positive effect on earnings informativeness.

\section{Hypothesis 2: Environmental costs have positive association with bank's size.}

Also, it is worthy to note from Table 4 that company size (measured with log of total asset) have positive as significant association with environmental costs reported by the company. These notion is evidenced with the prior study by Shi and Ban (2016) whom also found a positive association between company size and environmental performance. Watts and Zimmerman (I986) argued that larger firms would have higher political costs because the firms are more politically visible and may attract more resentment due to their perceived market power. They maintain that firm size is a comprehensive variable, which can proxy several cooperate attributes, such as competitive advantage, information production costs and political costs.

\section{Hypothesis 3: Environmental costs have a positive association with leverages}

Result of this study as depicted in Table 4 also found that leverages has positive and significant association with environmental costs. The implication is that the higher the leverage the higher the environmental costs to be incurred by the company. Jensen $\&$ Meckling (1976); Myers (I977) asserts that political transfers of wealth, from bondholders to shareholders can take place in highly leveraged firms.

\section{Conclusion}

This paper examines the determinants of environmental cost such as donation to charitable organization and development with reference to the influence of profitability, company size and leverages. Using all the fifteen (I5) banks listed on the Nigeria Stock Exchange websites as at March 30, 2019. The study utilizes archival data i.e the annual report of these banks from 2014 -2017 to extract the needed information. Based on the analysis, the study found that profitability, company size and leverages are positive and significantly associated with the environmental cost.

Therefore, the study recommended that to adapt to the changing system of doing business, accountants should be trained on environmental accounting and reporting, and in order to enhance competitiveness, banks should formulate and implement environmentally friendly policies. Finally, small entrepreneurs should be encouraged to report and disclose environmental impact activities in their annual reports and accounts and should not be left to big firms alone.

\section{References}

Abbott, L. J., Parker, S., Peters, G. F., \& Raghunandan, K. (2003). The Association between Audit Committee Characteristics 
and Audit Fees. AUDITING: A Journal of Practice \& Theory, 22(2), I7-32. https://doi.org/I0.2308/aud.2003.22.2.17

Abbot, W.F., \& Monsen, R.J. (1979). On the measurement of corporate social responsibility: self-reported disclosures as a method of measuring corporate socila involvement. Academy of Management Journal. 9(2), 65-71.

Ahmed, N. U., Montagno, R. V., \& Naffzigger, D. W. (2003). Environmental concerns, effort and impact: an empirical stud. Mid-American Journal of Business, I8(I), 6I-69.

Ayoib, C. A., Houghton, K. A., \& Nor Zalina, M. Y. (2006). The Malaysian market for audit services: ethnicity, multinational companies and auditor choice. Managerial Auditing Journal, 2I(7), $702-723$. https://doi.org/I0.I I08/026567102I04I5703

Bassey, B. E., Effiok, S. O., \& Eton, O. E. (2013). The Impact of Environmental Accounting and Reporting on Organizational Performance of Selected Oil and Gas Companies in Niger Delta Region of Nigeria, 4(3), 57-74.

Bhasin, M. L. (2016). The Challenge of Improving Corporate Governance by Creating Effective Audit Committees. International Journal of Management Sciences and Business Research, 5(8).

Bowman, E.H., \& Haire, M. (I975). A strategic Posture Towards Corporate Social Responsibility. California Management Review, I8(2), 49-58.

Dowling, J., \& Pfeffer, J. (I975). Organizational legitimacy: Social values and organizational behavior. Pacific Sociological Review, I8, I22-I36.

Fry, F. L., \& Hock, R. J. (1976). Who claims corporate social responsibility? "The biggest and the worst." Business and Society Review, I8(I8), 62-65

Gujarati, D. N., \& Porter, D. C. (2009). Causality in economics: The Granger causality test. Basic Econometrics (Fifth International Ed.). New York: McGraw-Hill.

Hair Jr, J. F., Black, W. C., Babin, B. J., Anderson, R. E., \& Tatham, R. L. (2010). SEM: An introduction. Multivariate Data Analysis: A Global Perspective, 629-686.

Hair, J. F., Black, W. C., Babin, B. J., Anderson, R. E., \& Tatham, R. L. (2010). Multivariate Data Analysis. Prentice Hall.

Henri, J. F., \& Journeault, M. (2010). Eco-control: The influence of management control systems on environmental and economic performance. Accounting, Organizations and Society, 35(I), 63-80.

Herawaty, V. (2018). The effect of environmental performance and accounting characteristics to earnings informativeness The effect of environmental performance and accounting characteristics to earnings informativeness. In The 4th International Seminar on Sustainable Urban Development. https://doi.org/I0.1088/I755-13I5/I06/I/012077

Hilmi. (2016). Effect of social and environmental performance financial performance of the company. European Journal of Accounting, Auditing and Finance Research, 4(9), 30-59.

Jensen, M. C., \& Meckling, W. (1976). Theory of the firm: managerial behavior, agency costs and ownership structure. Journal of Finance Economics, 3.

Lako A. (20II). Deconstruction of CSR and Business Paradigm. Reform and Akuntansi.Jakarta. Erland.

Lang, M., \& Lundholm, R. (1993). Cross-sectional determinants of analyst ratings of corporate disclosures. Journal of accounting research, 3I(2), 246-27I.

Leftwich, R. W., Watts, R. L., \& Zimmerman, J. L. (I98I). Voluntary corporate disclosure: The case of interim reporting. Journal of accounting research, 50-77.

McWilliams, A. \& Siegel, D. (2000). Corporate social responsibility and financial performance: Correlation or misspecification? Strategic Management Journal, 21, 603-609.

Myers, S. C. (1977). Determinants of corporate borrowing. Journal of financial economics, 5(2), I47-I75.

Mobus, J. L. (2005). Mandatory environmental disclosures in a legitimacy theory context. Accounting, Auditing, and Accountability Journal, I8(4), 492-5I7.

Owen, D. (2008). Chronicles of wasted time?: A personal reflection on the current state of, and future prospects for, social and environmental accounting research. Accounting, Auditing \& Accountability Journal, 2I(2), 240-267.

Pallant, J. (201 I). SPSS Survival Manual 4th edition: A step by step guide to data analysis using SPSS version I8. Maidenhead, Berkshire: Open University Press. Retrieved on from http://www. allenandunwin. com/spss.

QinYing, and Wu-Chun Y. (2004). An relationship research on the theory and model between enterprise environmental performance and economic performance. Theory and Practice Research of system engineering, (8), III-II7.

Rakhiemah, A. N., \& Agustia, D. (2009). Pengaruh kinerja lingkungan terhadap corporate social responsibility (CSR) disclosure dan kinerja finansial perusahaan manufaktur yang terdaftar di Bursa Efek Indonesia. Simposium Nasional Akuntansi XII, 4-6.

Ramsey, J. B. (1974). Classical model selection through specification error tests. Frontiers in Econometrics, I3-47.

Sekaran, U., \& Bougie, R. (2013). Research methods for business. In Research methods for business (p. 436).

Schiopoiu Burlea A., Popa I. (2013). Legitimacy Theory. In: Idowu S.O., Capaldi N., Zu L., Gupta A.D. (eds) Encyclopedia of Corporate Social Responsibility. Springer, Berlin, Heidelberg. 
Selcuk, E. A., \& Kiymaz, H. (2017). Corporate Social Responsibility and Firm Performance : Evidence from an Corporate Social Responsibility and Firm Performance : Evidence from an Emerging Market. Accounting and Finance Research, 6(4). https://doi.org/I0.5430/afr.v6n4p42

Semykina, A., \& Wooldridge, J. M. (2013). Estimation of dynamic panel data models with sample selection. Journal of Applied Econometrics, 28(I), 47-6I.

Skinner, D. J. (1994). Why firms voluntarily disclose bad news. Journal of accounting research, 32(I), 38-60.

Susi, S. (2005). The relationship between environmental performance and financial performance of Indonesian companies. Jurnal Akuntansi \& Keuangan, 7, 89-98.

Shi, X. Y., \& Ban, J. G. (2016). The Research on the Relationship Between Environmental Performance and Financial Performance. Journal of Finance and Accounting, 4(2), 8I-85. https://doi.org/I0.I I648/j.jfa.20160402.18

Tabachnick, B. G., \& Fidell, L. S. (2007). Multivariate analysis of variance and covariance. Using Multivariate Statistics, 3 , 402-407.

Tilling, M. V., \& Tilt, C. A. (2010). The edge of legitimacy: Voluntary social and environmental reporting in Rothman's I956-1999 annual reports. Accounting, Auditing, and Accountability Journal, 23(I), 55-8I.

Zikmund, W. G., Carr, J. C., Griffi, M., \& Fuller-jacobsen, B. (2010). Business Research Methods. South-Western, Cengage Learning, 8(I), I-I8.

\section{Copyrights}

Copyright for this article is retained by the author(s), with first publication rights granted to the journal. This is an open-access article distributed under the terms and conditions of the Creative Commons Attribution license (http://creativecommons.org/licenses/by/4.0/). 